\title{
Assessing U.S. Agricultural Export Growth Under North American Free Trade Agreement: A Shift-Share Analysis
}

\author{
Osei Yeboah \\ North Carolina A\&T State University \\ Victoria G. Tanoh \\ North Carolina A \&T State University \\ Saleem Shaik \\ North Dakota State University
}

\begin{abstract}
NAFTA is the first free-trade pact that has transformed and driven economic integration among the United States, Canada, and Mexico. The three NAFTA countries' agricultural export performance in four major classified commodities was each analyzed prior to the implementation and active years of NAFTA by applying a dynamic shift share model to data from 1992 through 2018. The overall results show United States was found to be the overall beneficiary NAFTA among the participating countries. The U.S. led in the exports of all the four major classified agricultural commodities followed by Canada, and then, Mexico. The most highly exported commodity among the four by any of the member nations, was consumer-oriented products while agricultural-related, intermediate, and bulk commodities follow in that order.
\end{abstract}

Keywords: Free Trade Agreement, NAFTA, shift-share analysis, U.S. agricultural export

\section{INTRODUCTION}

The United States has been an active participant in numerous regional free trade agreements (FTAs) with other countries over the years. Free trade agreements allow member countries to eliminate tariffs and non-tariff barriers on trade in goods while the countries involved maintain their trade policies. The U.S. is a partner to FTAs with 20 countries. These FTAs include a mix of twelve bilateral agreements and two Regional Trade Agreements (RTA). The regional trade agreements include North American Free Trade Agreement (NAFTA) and the Dominican Republic-Central America-United States Free Trade Agreement (CAFTA-DR), (USTR, 2020). Free trade agreements also allow member countries to eliminate tariffs and nontariff barriers on trade in goods while each country maintains its trade policies. (Congressional Research Report, 2014). These agreements generally offer numerous benefits to the participating countries mainly by facilitating accessibility to another's market. Arguably, NAFTA, which was implemented on January 1st, 1994 to replace the existing five-year Canada-US Trade Agreement (CUSTA) with the introduction of Mexico to form a trilateral trade agreement was the largest regional trade agreement entered by the United States. It was the bulkiest free trade pact outside of the European Union and the first reciprocal free-trade 
pact between a substantial developing country and developed economies (Hufbauer \& Schott, 2005). At the time of the implementation of NAFTA, the US-Canada FTA was already in effect, and U.S. tariffs on most Mexican goods were relatively low, while Mexico had the highest protective trade barriers. Under the agreement, the United States and Canada gained greater access to the Mexican market, which was the fastest growing major export market for U.S. goods and services at the time. (US Congressional Report, 2020; USITC Report, 1993).

The trade agreement transformed North American economic relations by driving integration between the developed economies of the United States, Canada, and Mexico's developing one. NAFTA played a key role in the integration of North America's agricultural markets. The implementation of NAFTA has had a significant impact on trade within the North American region. Trade among the three- member countries from 1993 to 2019 has quadrupled from \$290 billion to \$1.23 trillion. U.S. trade with partner countries under NAFTA contributed to $74.8 \%$ or $\$ 1.2$ trillion of total U.S. trade with FTA partners. Total U.S. exports to NAFTA countries increased by $7.3 \%$, a value of $\$ 563.7$ billion from 2017 to 2018 (U.S.TR Report, 2018). The export share of U.S. agricultural production also grew at an average of 20 percent from 2011 to 2013. This increase can largely be ascribed to NAFTA (U.S.TR Report, 2018). The share of U.S. agricultural export to Canada and Mexico increased from 28\% in 1993 to $128 \%$ in 2016. U.S., Food and agricultural export to Canada and Mexico have also increased significantly from \$11billion in 1993 to \$43 billion in the same year (U.S. Census Bureau, 2016). In 2019, U.S. agricultural exports to the world were about $\$ 136.7$ billion with Canada and Mexico remaining as the top two trading partners. Canada represented $15 \%$ of total U.S. agricultural exports which amounted to $\$ 20.8$ billion. The highest agricultural export growth was in $\operatorname{dog} \&$ cat foods with an increase of $16 \%$ followed by fresh vegetables, live animals, and pulses. Mexico was the second-largest U.S. agricultural exports with a total of 19.2 billion (USDA, ERS, 2020). The United States is the largest supplier of agricultural goods in Mexico with a $69 \%$ market share.

In the bid to extract more benefits from NAFTA, the previous U.S. administration renegotiated with the member countries to form the United States-Mexico-Canada Agreement (USMCA). The USMCA builds on the fundamentals of NAFTA and then goes on to further improve the provisions under the trade agreement. The Trump administration on January $20^{\text {th }}, 2020$ signed the USMCA into law. This agreement is to deepen the agricultural trade among member countries by the introduction of key provisions on biotechnology, geographical indication, and stricter enforcement of sanitary and phytosanitary measures, poultry and eggs, wheat, wine, and spirits. Under the agreement, all agricultural products that have zero tariffs under NAFTA will remain at zero tariffs. (USDA ERS, WRS-15-01). There have been several research articles written on the benefits of bilateral and regional trade agreements across the world, and that have led to an increase of about 30 to 114 percent in each partner's trade over a 10-year period after an agreement has entered into force, NAFTA was one of the most controversial trade agreements the United States had participated with varying viewpoints and criticism on its benefits. Despite the controversies that surrounded the implementation of NAFTA, it has been known as the most comprehensive FTA negotiated so far and has had several groundbreaking provisions, serving as template for the new generation future FTAs (USITC, 2016). Although there is substantial research on this trade agreements overall, only a limited number of retrospective studies that have addressed the agreement from inception to conclusion. This study provides a retrospective analysis of the agricultural export performance by disentangling the impact of the trade agreement from other economic conditions that may have coincided with the implementation of NAFTA, thereby aiming to distinguish its incremental impact on the trading countries. The current research provides an overall assessment of U.S. agricultural growth under NAFTA by employing dynamic shiftshare model to analyze the export growth of four major classified commodities as a measure of the gains from trade under NAFTA. A modified shift-share analysis is employed to U.S., Canada and Mexico's agricultural exports and further disaggregated into the bulk, intermediate, consumer, and agriculturalrelated products for the period of NAFTA's implementation from 1994 to 2018. Previous assessment on the U.S. trade gains from NAFTA using the shift-share model has tended to focus on employment as the main economic variable of interest. However, this study considers agricultural exports of any of the three NAFTA trading countries for the period as the main economic interest. The dynamic shift-share analysis employed is used to examine the overall agricultural export performance of members countries' export 
performance relative to o the Rest of the World (ROW). Further, the various product categories within the agricultural industry are analyzed to determine the sectorial shifts for the period under study.

The rest of the paper is structured as follows: Section 2 presents a brief reviewed literature on NAFTA and the applied model while Section 3 provides the theoretical and empirical framework of the shift share analysis; presented in Section 4 are the sources of data, construction, and estimation procedures while the results and discussions are presented in Section 5; Section 6, summary, and conclusion.

\section{LITERATURE REVIEW ON NAFTA}

The implementation of the North American Free Trade agreement has had a significant impact on trade within the North American region. Trade among the three member countries from 1993 to 2019 has quadrupled from $\$ 290$ billion to $\$ 1.23$ trillion. U.S. trade with partner countries under NAFTA contributed to $74.8 \%$ or $\$ 1.2$ trillion of total U.S. trade with FTA partners. The U.S. export to NAFTA countries increased by $7.3 \%$, measuring up to $\$ 563.7$ billion from 2017 to 2018 (U.S.TR report, 2018). The export share of U.S. agricultural production has also grown at an average of 20 percent from 2011 to 2013. This increase can largely be ascribed to NAFTA (U.S.TR Report 2018).

De Janvry, Sadoulet, and Davis (1997) in their assessment of NAFTA highlighted that the agricultural transition structure under the agreement was made up of three separate bilateral agreements subsumed into one compact trade agreement. The positive effect of the agreement cannot be overemphasized with the increasing number of imports and exports among member countries. The share of U.S. agricultural export to Canada and Mexico increased from 28\% in 1993 to $128 \%$ in 2016. U.S. food and agricultural export to Canada and Mexico have increased significantly from \$11billion in 1993 to \$43 billion in 2016 (U.S. Census Bureau, 2016).

In 2019, U.S. agricultural exports to the world were about $\$ 136.7$ billion with Canada and Mexico remaining as the top two trading partners. Canada represented $15 \%$ of total U.S. agricultural exports which amounted to \$20.8billion. The highest agriculture export growth was in dog \&cat foods with an increase of $16 \%$ followed by fresh vegetables, live animals, and pulses. Mexico was the second-largest U.S. agricultural exports with a total of 19.2 billion (USDA, ERS, 2020). The United States is the largest supplier of agricultural goods in Mexico with a $69 \%$ market share.

\section{LITERATURE REVIEW ON THE SHIFT-SHARE MODEL}

From Graham and Nigel (1997), shift share models can be used to assess the degree to which patterns of regional employment change may have been influenced by either the structural composition of regional industries or by some unique locational or competitive effects inherently within the regions themselves. This technique was developed by Creamer (1942) in the United States to measure growth trend differences between the nation and its states. The main aim of the model is to separate national level economic components from regional industrial and economic effects. A lesser goal is to explain why regional economic conditions may differ from national level trends. A shift share analysis helps identify industries where a regional economy has competitive advantages over a larger economy. The classical shift share model is used by regional economists to provide an overview of the economic landscape of both rural and urban areas (Selting \& Loveridge, 1992). It provides a straightforward approach to separating out the national and industrial contributions from the local growth while providing useful insights on industries that may be experiencing growth or lags. Since economic growth is relatively difficult to measure directly, changes in regional employment are widely used for economic growth. Implicit in shift share analysis is the assumption that regional economies should grow at national growth rates unless there are comparative advantages or disadvantages operating at the regional level (Selting \& Loveridge, 1992; Bishop \& Simpson,1972).

Esteban-Marquillas (1972) introduced the concept of homothetic employment thereby extending the classical shift share model to overcome a major weakness highlighted by critics of the shift share model on 
the failure of the competitive effect to measure employment growth due to the special dynamism of the sector in the region.

McDonough and Sihag (1989) extended the traditional model to formulate the international shift share formula with world growth and world industry mix effects. The study argued that certain industries compete internationally, and the regional growth of these industries could be linked to specialization. Regional competitive advantages are dependent on factors such as wage rates, taxes, and energy cost differences while national competitive advantage depends on macroeconomic conditions such as foreign exchange rates, monetary and fiscal policies (McDonough et al.,1989).

Following the extension of shift share analysis on the international front, Markusen, Noponen and Driessen (1991) developed further, an extension of the model to analyze trade issues by decomposing the components of the model into import, export, domestic market segments and a productivity component. The dynamic shift share model employed in the study has nine components as compared to the traditional shift share which attempted to assess the effects of the nation's export and import performance on individual regions. The national growth and industrial mix components are disintegrated into four components each while the competitive mix remain unchanged.

Dinc and Haynes (1998) provides further notes on the extension model by Markusen et al. (1991) by investigating the impact of international trade. The study recommended modifications to the previous formula by arguing that exported and domestically consumed goods are produced by the same labor force at the same place. Hence, actual employment should be the summation of employment due to export and employment attributed to domestic consumption. This implies that increase in exports and domestic demand will create an increase in employment while increase in imports could cause a decrease in employment.

Further study on international trade using the international shift share analysis was carried out by Oyewole (2016) to investigate the winners of world market share in four sectors of the service exports over a 15-year period from 1997 to 2012. The specific growth indicator was service export values in current U.S. dollars over the stated period for all countries of the world categorized into seven regions. The study concludes that Europe and Central Asia gained the most in the world market share of service.

Wilson, Chem, Ping, and Robinson (2005) assessed the export competitiveness of Singapore within the East and Southeast Asian economies by applying the dynamic shift share model to the electronic manufacturing industry. The analysis revealed that, between 1991 to 1995, Singapore experienced increased trade flows within the East and Southeast region after the formation of the ASEAN Free Trade Area (AFTA). (Wilson et al., 2005) introduced the interactive effect to illustrate the extent to which the export differential is attributable to the combination of the competitive and the industry mix effect. The authors explained that this will have a positive effect if the competing economies within the region specializes in commodity exports to which it has comparative advantage or minimal of commodities with no such advantage.

\section{THE THEORETICAL FRAMEWORK}

The traditional shift share model also known as the comparative static approach (Barff, 1988) was introduced by Creamer (1942) and summarized by Dunn (1960) to assess the shifts in the economic activity in a region (Shi \&Yang, 2008; Herath, Gebremedhin \& Maumbe, 2011). Creamer (1942) developed the concept of the "location shifts" used to measure growth trend differences between the nation and the various states within it. The purpose of the technique was to assess the regional growth or decline by evaluating the foundations of the economic performance within a region. Hence providing a descriptive tool that isolates trends in regional performance and supplies data for policymakers to interpret changes in the industrial structure of their economies. The model basically consists of disaggregating the growth in an indicator of interest such as exports from one period to another into three main components. The traditional shift share model decomposes the growth in the economic variable over a given period of times into three components as follows:

Actual Growth $=$ National share + Industry mix + Regional share

Journal of Applied Business and Economics Vol. 23(6) 2021 
The model suggests that the actual growth in an economic variable can be explained by the aggregation of the national, industry and regional effects. The model can be mathematically stated as:

$$
\Delta E_{i, j}=N E_{i, j}+I_{i, j}+R E_{i, j}
$$

where:

$$
\begin{aligned}
& I=1,2,3,4 \\
& i=\text { the aggregate commodity group in a specific industry } \\
& j=1,2,3 \ldots \text { representing agricultural export from any origin to any destination country } \\
& t=\text { time- period } \\
& \mathrm{G}=\text { national growth rate in all industries } \\
& \mathrm{G}_{i}=\text { national growth rate in specific industry } \\
& g_{i}=\text { regional growth rate in the specific industry } \\
& \Delta E_{i, j-2}=\text { the actual growth or change in industry i from one country to the other trading partners }
\end{aligned}
$$

The national growth component is represented by NE while IM and RE represents the industrial mix and regional share component, respectively.

The national growth component, also referred to as the reference area component focuses on the national economy which measures the regional growth that would have occurred if the regional economy had grown at the same rate as that of the national trend. This effect measures how much economic growth in a region can be attributed to the overall growth rates in the national economy. It is simply the portion of the total growth in a region attributed to the rate of growth in the reference area. The national share is computed as:

$$
\mathrm{NE}=\mathrm{E}_{\mathrm{ij}-1} * \mathrm{G}
$$

The industrial mix component represents the portions of the overall agricultural export growth explained by the national growth rate for the specific commodity group. It measures the agricultural sector composition illustrating the growth among the four major commodity groups to determine the ones growing slowly or faster nationally. Hence a nation with relatively large share of commodity groups growing relatively faster than the national trend will have a positive industrial mix and vice versa. The industry mix captures the regional variations in the agricultural sector composition. Ideally, the sum of the national and industry components should be equal to the expected change. The product mix component is computed by multiplying the initial value of the agricultural export by the region by the resultant of the differential value between the national commodity group growth rate and the overall national growth rate. The industry component is expressed as equation (4) below

$$
\mathrm{IM}=\mathrm{E}_{\mathrm{i}, \mathrm{j}-1} *\left(\mathrm{G}_{\mathrm{i}}-\mathrm{G}\right)
$$

The regional or competitive effect is the residual after considering national and industry mix shares. It is, therefore, the residual after the national and industry mix effect are allowed for. The regional effect shows the level of growth of the various agricultural commodity groups within a region due to local or unique economic factors. The regional share in a broader sense is seen as the difference between the actual and the expected change. The regional effect may result from the unique endowments of the region, effects of regional policies, comparative advantages or disadvantages and other factors such as the entrepreneurial ability of the region (Dinc \& Haynes, 2005).

The regional mix is computed by multiplying the difference between the various regional commodity groups growth rates and that of the national by the initial value of the agricultural exports to the region. The regional component is stated as: 
Regional share $=\mathrm{E}_{\mathrm{i}, \mathrm{j}-1} *\left(\mathrm{~g}_{\mathrm{i}}-\mathrm{G}_{\mathrm{i}}\right)$

The total shift or the actual growth measures the region's economic position relative to the reference area. The traditional shift share model has been extended and applied in several international trade studies including Sihag \& McDonough (1989) that extended the traditional model to incorporate the international effect. The study argues that for a region to maintain competitive advantage in production for a specific sector, the industries in which the region specializes must experience growth in the industry internationally. The conclusion from the study on the extension of the shift share analysis to international studies affirmed that a detailed analysis is needed to identify the sources of the competitive component and proposed a multiple regression analysis. The traditional model utilizes only the beginning and ending years of the period under review and neither take into consideration the changes in the various components over time nor the continuous changes in the volume of the region's export over the period. The main distinguishing difference between the traditional and the dynamic shift share is that the dynamic shift share utilizes the incremental effect of the data from each successful year within the period under consideration. Over the years, researchers have attempted to improve the traditional shift share by incorporating various approaches into the model. Stillwell (1969) proposed using the weights from the final year instead of the first year while others including Fuchs (1962) proposed using the average for both the beginning and last weight as a means of accounting for the changes in the regional structure for the period. This paper utilizes the proposal of Fuchs (1962) in the estimation of the dynamic shift share as indicated in the empirical model.

\section{The Empirical Model}

Many adjustments have been made to the traditional shift share model to measure the growth of various economic variables of interest since its formal inception. Wilson et al. (2005) applied the dynamic model in their analysis to estimate the competitiveness of the electronic manufacturing industry in Singapore among East and Southeast Asian economies. The variable of interest from Wilson (2000) was volume of export, and the national growth rates approach of Richardson (1978) and Esteban-Marquillas (1972) all within the framework of the dynamic. Following the explanation of Fuchs (1962) on the components of shift share analysis, the dynamic shift share analysis employed in this current study considers adjustments by the various years and utilizes the changes in the annual growth rates. Again, the weights of the average of base and terminal weights were utilized as suggested by Fuchs (1962) to curb the challenge of base weighting which has been heavily popularized by most critics of the model. The summation of the effects over a period illustrates the contributions of continuously changing effects to total growth over long periods of time as presented in equation ( 6 ).

The modified model is expressed as follows:

$$
\text { Agricultural Export Growth }=\text { ROW component }+ \text { Product Mix component }+ \text { NAFTA effect }
$$

For each effect, the sector values are summed to obtain the total effect. The model is stated as:

$\Delta \mathrm{Ex}_{\mathrm{i}, \mathrm{j}}=\sum_{\mathrm{i}, \mathrm{j}} \mathrm{ROW}+\sum_{\mathrm{i}, \mathrm{j}} \mathrm{PM}+\sum_{\mathrm{i}, \mathrm{j}} \mathrm{NAFTA}$

The $i$ represents the classified commodity group i.e., the bulk, intermediate, consumer and agricultural related products while $j$ represents the region of agricultural export destination which is either ROW, or Canada and Mexico. The growth rate of U.S. agricultural export of these commodities to Mexico and Canada is represented by $r_{i(j-2)}$. The agricultural export growth rate from the U.S. to the ROW is represented by $r_{w}$; and $r_{w i}$ is the growth rate of U.S. agricultural export categorized into the four aggregate commodity groups to the Rest of the World. U.S. agricultural export by commodity group to Mexico and Canada is characterized by $\mathrm{E}_{\mathrm{ij}-2}$ The national share in the traditional shift share model constitutes the broad reference area. Similarly, the national share in our empirical model represents the ROW effect. Therefore, it explains 
the growth or decline that would have occurred if U.S. agricultural export to the NAFTA partners had grown at the same rate as U.S. agricultural export to Rest of the World

\section{DATA SOURCE}

The data source from the Global Agricultural Trade Systems of the Foreign Agricultural Services (USDA-FAS,2020) supplies information on U.S. export values in thousands of dollars for bulk, intermediate, and consumer commodities from 1989 to 2018. Bulk commodities consist of wheat, corn, coarse grain, rice, soybeans, oilseeds, cotton, pulses, tobacco, while soybean meal, soybean oil, vegetable oil, animal fats, live animals, hides and skins, hay, distillers' grains, feeds, and fodders nesoi, planting seeds, sugar, sweeteners, beverage bases constitute intermediate.

Consumer Oriented are made up of beef and beef products, pork and pork products, poultry meat and products, meat products nesoi, eggs and products, dairy products, fresh fruit, processed fruit, fresh vegetables, processed vegetables, fruit and vegetable juices, tree nuts, chocolate and cocoa products, snack foods nesoi, breakfast cereals, condiments and sauces, prepared food, non-alcoholic beverages, dog, and cat food; and agricultural related products include distilled spirits, ethanol, biodiesel, and blends $>$ b30, forest products, fish products (USDA-FAS, GATS 2020).

\section{Estimation Procedures and Data Construction}

The variables in the model are constructed by using agricultural exports segregated into bulk, intermediate, consumer oriented, and agricultural related products from any of the three NAFTA trading partners as the dependent variable. The explanatory variables are the value of agricultural export from one of the NAFTA countries to the Rest of the World as the main reference region, the Product mix effect, and the NAFTA effect. Therefore, the U.S. Agricultural export growth for the study period is explained as the sum of the ROW effect, the Product mix, and the NAFTA effects.

Equation (6) was applied to the data described above and analyzed using the Microsoft excel software. Growth rate for the ROW $\left(r_{w}\right)$ is computed as the sum of the difference between the U.S. agricultural exports to the (ROW) from year ${ }_{t-1}$ to $t$ divided by the value for year ${ }_{t-1}$, and the result, expressed as a percentage. The current period at any point in time is denoted by $t$ while $t_{t-1}$ is the previous year. The growth rate of U.S. agricultural export to ROW for the period is computed as the sum of the difference between the agricultural exports for any year and its preceding year divided by the preceding year all through the period under consideration. It is computed as the growth rate of exports from the U.S. to the ROW multiplied by the aggregate result of U.S. agricultural export value to Mexico and Canada for the period. The ROW growth effect computed as:

ROW growth effect $=r_{w} * E_{i j-2}$

The Product mix effect in our empirical model is a modified version of Creamer's traditional model as expressed in equation (4). The product mix refers to the composition of the specific agricultural product categories and reflects the product types that are growing or declining compared to the ROW region in this study. The product mix in our empirical model is computed as in equation 8 as:

Product mix effect $=\mathrm{E}_{\mathrm{ij}-2} *\left(\mathrm{r}_{\mathrm{wi}}-\mathrm{r}_{\mathrm{w}}\right)$

The NAFTA effect shows how the agricultural export of the four aggregate agricultural commodity groups grew due to unique economic factors that can solely be attributed to the implementation of NAFTA. It is computed by finding the difference between the growth rate of U.S. agricultural export by commodity groups to the other two NAFTA countries and the growth rate of U. S. agricultural export by product to the ROW, and then multiplying by the U.S. agricultural export value to the two countries.

The NAFTA effect is computed as: 
NAFTA effect $=E_{i j-2} *\left(r_{i(j-2)}-r_{w i}\right)$

Each country's agricultural export performance under NAFTA is analyzed separately to assess the effect of NAFTA on member nations' performance. This is done by comparing the agricultural export performance among the three trading partners prior to the implementation of NAFTA and during the active years of the free trade agreement. The Net shift is calculated as the difference between the ROW effect and the actual growth. Due to limited data on export data, the Pre-NAFTA period is only from 1989 to 1992. Finally, for the purpose of comparison and uniformity, the last four years of active NAFTA years from 2015 to 2018 were considered as post-NAFTA.

\section{RESULTS AND DISCUSSIONS}

Table 1 illustrates the distribution of export of the four classified agricultural commodities from the NAFTA countries to the rest of the world (ROW) from 1994 through 2018.

All the three North American countries made significant contributions toward global export of these commodities during the period. The annual average contribution for the three trading nations to the ROW was $\$ 48.78$ billion during the implementation phase. Among these three regional partners, the United States consistently ranked the highest for all the major commodities followed by Canada, and Mexico. Agricultural exports of bulk commodities to the ROW which was dominated by grains and oil seeds was the highest. Exports of consumer-oriented goods came second with $\$ 26.2$ billion, followed by $\$ 15.2$ billion for Intermediate goods while agricultural related contributed $\$ 13.5$ billion. 


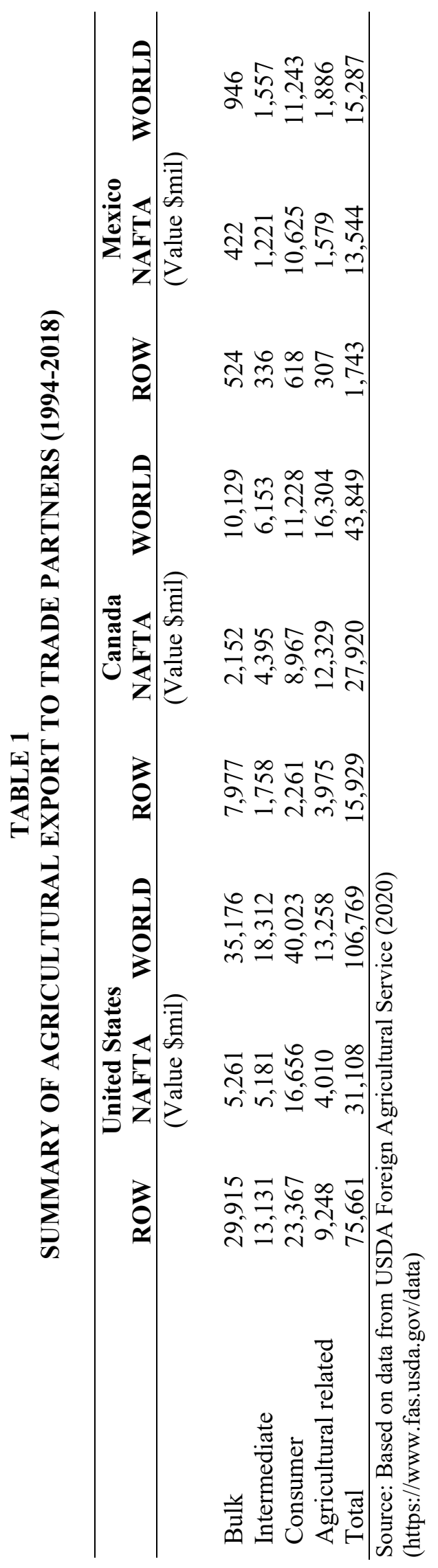




\section{TABLE 2}

SUMMARIZED SHIFT SHARE ANALYSIS ON AGRICULTURAL EXPORT PERFORMANCE (PRE-NAFTA, 1989-1992 AND POST NAFTA ERA, 2015-2018, VALUE \$ MILLION)

\begin{tabular}{|c|c|c|c|c|c|c|}
\hline Country & Period & $\begin{array}{l}\text { Actual } \\
\text { Growth }\end{array}$ & ROW effect & $\begin{array}{l}\text { Product } \\
\text { mix effect }\end{array}$ & $\begin{array}{l}\text { Regional Effect } \\
\text { (US/C/M)/NAFTA }\end{array}$ & $\begin{array}{l}\text { Net Total } \\
\text { Shift }\end{array}$ \\
\hline \multirow{4}{*}{ USA } & $\begin{array}{c}\text { Post } \\
\text { NAFTA }\end{array}$ & $-1,683$ & $-3,266$ & 1,951 & -368 & $-1,583$ \\
\hline & & $-100 \%$ & $-194 \%$ & $116 \%$ & $-22 \%$ & \\
\hline & $\begin{array}{c}\text { Pre- } \\
\text { NAFTA }\end{array}$ & 2,227 & 1,204 & 1,049 & -26 & $-1,023$ \\
\hline & & $100 \%$ & $54 \%$ & $47 \%$ & $-1 \%$ & \\
\hline \multirow{5}{*}{ Canada } & Post & & & & & \\
\hline & NAFTA & 6,129 & $-5,988$ & $-2,058$ & 14,175 & $-12,117$ \\
\hline & & $100 \%$ & $-98 \%$ & $-34 \%$ & $231 \%$ & \\
\hline & $\begin{array}{c}\text { Pre- } \\
\text { NAFTA }\end{array}$ & 6,237 & -468 & 1,531 & 5,174 & $-6,705$ \\
\hline & & $100 \%$ & $-8 \%$ & $25 \%$ & $83 \%$ & \\
\hline \multirow{4}{*}{ Mexico } & $\begin{array}{c}\text { Post } \\
\text { NAFTA }\end{array}$ & 5,835 & 2,544 & 2,780 & 511 & $-3,291$ \\
\hline & & $100 \%$ & $44 \%$ & $47 \%$ & $9 \%$ & \\
\hline & $\begin{array}{c}\text { Pre- } \\
\text { NAFTA }\end{array}$ & 5,208 & 3266 & 1762 & 180 & $-1,942$ \\
\hline & & $100 \%$ & $63 \%$ & $34 \%$ & $3 \%$ & \\
\hline
\end{tabular}

Source: Based on data from USDA Foreign Agricultural Service (2020)

(https://www.fas.usda.gov/data)

Table 2 presents the results of the shift share analysis with agricultural export growth into ROW, Product Mix, and NAFTA effects as well as the net Total Shifts. The entries for the actual growth illustrate the agricultural growth or decline for each country under the pre- and post- NAFTA eras for the selected years.

\section{Results of the Analysis for United States Under Pre- and Post-NAFTA}

The U.S'. exports to other member countries under pre-NAFTA, showed an actual growth of \$2.3 billion. This represents the summation of all the various components listed in table 2 above. The ROW effect of $\$ 1.20$ billion represents the export growth of U.S. that would have been gained if exports to Mexico and Canada had grown at the same rate as that to ROW. Also, the net shift of \$1.20billion accounts for the difference between the growth to ROW and the actual growth, signifying a surplus of $\$ 1.20$ billion (54\%). This result implies that U.S.' export to Mexico and Canada outgrew that to ROW by $54 \%$. This could be possibly attributed to the already existing CUSTA before the implementation of NAFTA.

The entries in the product mix column describes the adjustments in the differential export growth rates of the major classified commodities from the U.S. to the ROW relative to Mexico and Canada. The product mix effect of $\$ 1.04$ billion represents growth of U.S. aggregate exports which was a $47 \%$ increase in export value to Canada and Mexico relative to that of the ROW. In addition, the expected growth of 2.613 billion which is the sum of $\$ 1.20$ billion and $\$ 1.40$ billion exceeded the actual growth of $\$ 2.22$ billion for the 
period. The results indicate that U.S. export to Mexico and Canada fell short of $\$ 26$ million due to probably, the absence of a specific trade policies targeted at reducing trade tariffs among the three trading nations.

U.S.' agricultural exports, during the post NAFTA era showed a decline of \$1.68billion. The ROW effect shows a deficit of $\$ 3.26$ billion indicating the decline in U.S. export to Mexico and Canada relative to that of ROW. However, the results for the Product mix effect of $\$ 1.95$ billion revealed that the U.S. export of the major commodities to the ROW performed better than that to Canada and Mexico. The net shift also showed a surplus $\$ 1.58$ billion and contributes to the overall increase in exports from the U.S. to its regional trading partners. The NAFTA effect rather showed a $\$ 368$ million exports deficit to Mexico and Canada. This deficit is very little in comparison to the expected deficit of $\$ 2.26$ billion, that would have occurred in the absence of NAFTA.

\section{Results of the Analysis for Canada Under Pre- and Post-NAFTA}

Canada's agricultural export to U.S and Mexico experienced a decrease of \$108million (from $\$ 6.23$ billion before NAFTA down to $\$ 6.12$ billion post NAFTA). A deficit of $\$ 468$ million was also recorded for that of the ROW during pre-NAFTA. On the contrary, the product mix effect of $\$ 1.53$ billion shows that the country's export of the specific major products to U.S. and Mexico was greater than that to the ROW's industry trend. These products include consumer products such as dairy products which were of high demand in the U.S. This could be attributed to the effectiveness of CUSTA which was in place prior to NAFTA. Canada's ROW effect suggests a shortfall in agricultural export to U.S. and Mexico of \$5.98 billion compared to its export to ROW. The Product mix effect the same period towed the line of the ROW effect with a deficit of $\$ 2.05$ billion. This may be partly due to the dwindling export value of consumer product from Canada to Mexico especially for meat export from pork to beef. The share of Canada's pork to total meat export declined from $88 \%$ to $18 \%$ as of 2001 (Calberg \& Rude, 2004).

A significant growth however, occurred during post-NAFTA. A total of $\$ 14.17$ billion in the export was recorded in table 1 for Canada's NAFTA effect. This NAFTA effect of \$14.17 billion illustrates the significant gains Canada enjoyed from the trade agreement. For instance, Mexico's increase in demand for grain fed beef helped increase the demand for Canadian grains. This was also coupled by favorable supply factors including the elimination Canada's transportation subsidy (Western Grains Transportation Act) which led to a decline in the prices of feed grains in Western Canada. Finally, the country's increased access to the U.S. and Mexican markets through the Trade Act also helped increase the export of most agricultural commodities especially agricultural related commodities.

\section{Results of the Analysis for Mexico Under Pre- and Post-NAFTA}

Mexico's agricultural export performance was enhanced significantly as seen in table 1 . The overall agricultural export for Mexico's pre-NAFTA was \$5.2billion while the post NAFTA period was $\$ 5.83$ billion. The country, among all the three was the only nation to have experienced a significant increase in its agricultural export volume. For example, U.S. agricultural export declined from a surplus of $\$ 2.23$ billion to a deficit of $\$ 1.68$ billion which is an overall decline of $175 \%$. Canada also, had an overall agricultural export decline of $1.73 \%$ (from $\$ 6.24$ billion to $\$ 6.13$ billion). The ROW effect of $\$ 3.27$ billion for the Mexico's pre- NAFTA period indicates the country was performing better than its partners prior to the implementation of NAFTA. The product mix column describes the adjustments in the differential export growth rates of the major commodities from Mexico to the ROW relative to U.S. and Canada. The product mix effect of $\$ 1.76$ billion represents growth in the export of Mexico's aggregate products which was a $34 \%$ increase in the export value to U.S. and Canada relative to that of the ROW. Mexico's export growth that could be attributed to the unique advantages which include its proximity to U.S. and Canada under preNAFTA was $\$ 180$ million.

The post NAFTA agricultural growth for Mexico was $\$ 5.835$ billion segregated into $\$ 2.54$ billion of ROW effect, Product mix of $\$ 2.78$ billion, and \$511 million NAFTA effect. Mexico's net shift of \$3.29 billion for the post NAFTA period shows a positive shift of agricultural export from ROW to U.S and Canada. The product mix effect of $\$ 2.78$ billion was primarily driven by increase in exports of consumer products such as fruits and vegetables. The NAFTA effect of \$511 million indicates the positive shift of 
from $\$ 180$ million to $\$ 511$ million, an increase of $200 \%$, possibly, attributable to the implementation of NAFTA.

\section{FIGURE 1 \\ AGRICULTURAL EXPORT OF NAFTA COUNTRIES BY TRADE PARTNERS -AGGREGATE PRODUCT CATEGORIZATION (VALUES IN \$'BILLIONS 1994-2018)}

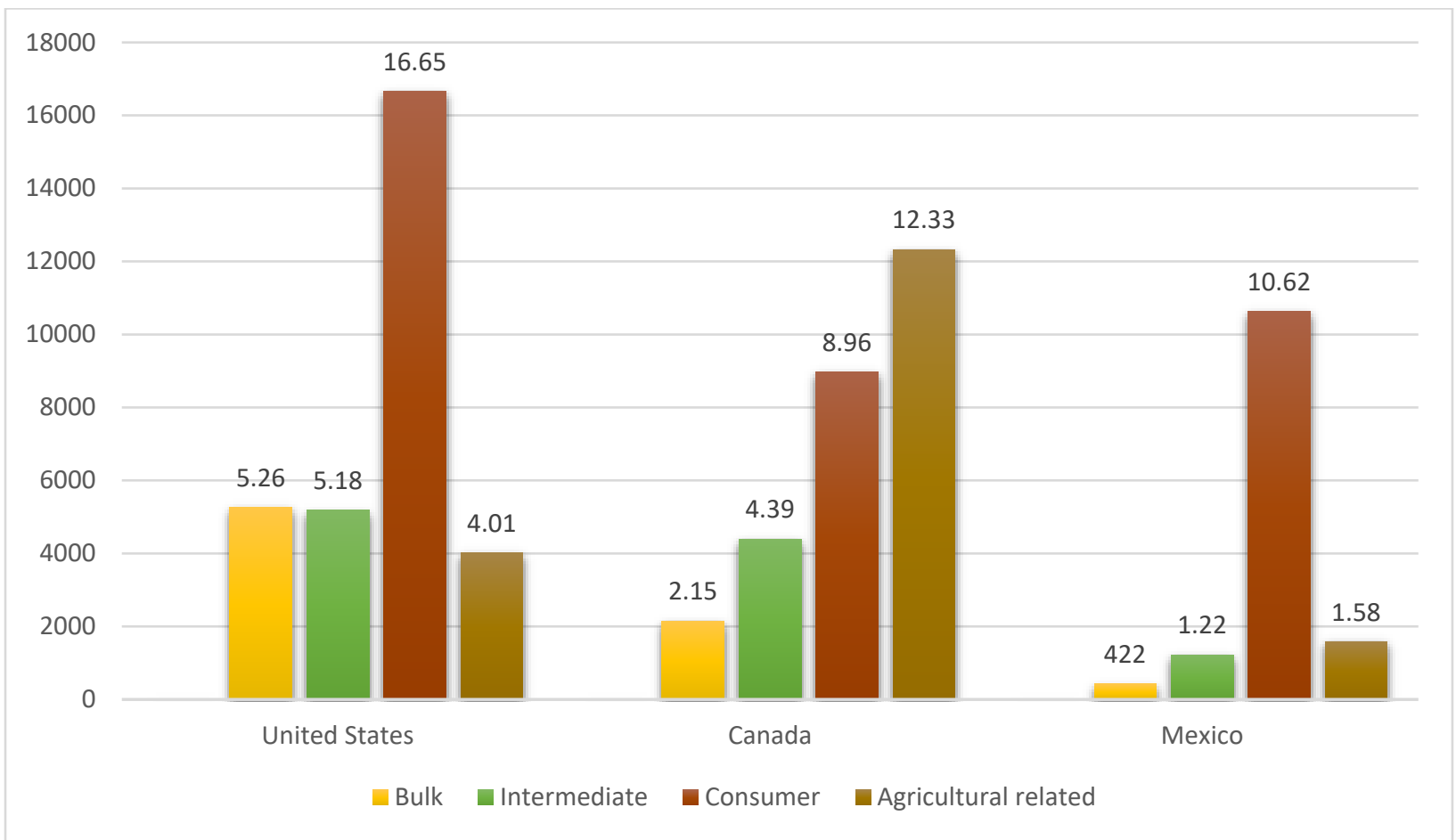

Source: Based on data from USDA Foreign Agricultural Service (2020)

(https://www.fas.usda.gov/data)

Figure 1 is a graphical representation of the overall agricultural export values for the three countries in the four major commodities from 1994 to 2018. Analysis from Figure 1 indicates that the United States was the overall leading exporter of the four major classified agricultural commodities followed by Canada, and Mexico.

U.S. agricultural exports to the NAFTA countries increased both at the aggregate and commodity levels with an overall average of $\$ 31.18$ billion. That of Canada and Mexico were $\$ 27.9$ billion and $\$ 13.54$ billion, respectively. The analysis also revealed that consumer-oriented goods from U.S. contributed most, \$16.6 billion an almost $54 \%$ of the U.S. total. The U.S. export of consumer product was the highest in comparison to Canada and Mexico. Exports of bulk commodities and intermediate came a distant second with $\$ 5.26$ billion each while agricultural related contributed $\$ 4.01$ billion.

Canada was the second largest exporter of the major agricultural commodities to the two-trading nation during the period. Agricultural related commodities were the highest contributor with an average of $\$ 12.30$ billion followed by consumer-oriented goods worth $\$ 8.96$ billion. Intermediate and bulk commodities took distant third and fourth places with $\$ 4.30$ billion and $\$ 2.25$ billion, respectively.

Mexico, despite its least ranked among the three-trading nations, the country's agricultural export volume has significantly been enhanced by NAFTA. On an average, the agricultural export of Mexico to U.S. and Canada during the period was $\$ 13.54$ billion whilst its agricultural export to the ROW during the same period was $\$ 1.74$ billion. The overall export growth of $\$ 13.54$ billion was heavily dominated by consumer-oriented products contributing $\$ 10.62$ billion. Agricultural related products and intermediate 
followed distant second and third with $\$ 1.55$ billion and $\$ 1.22$ billion respectively, while bulk commodities accounted for only $\$ 422$ million.

\section{SUMMARY AND CONCLUSION}

The aim of this paper was to provide an assessment of U.S. agricultural growth relative to Canada and Mexico under NAFTA by considering the exports of four major classified commodities as a measure of the gains from trade. The three trade partners' agricultural export performance in four major classified commodities was each analyzed prior to the implementation and active years of NAFTA by employing the dynamic shift share model to data from 1992-2018. The overall results show that United States was the overall of NAFTA. The U.S. led in the exports of all the four major classified agricultural commodities followed by Canada, and then, Mexico. The most highly exported commodity among the four by any of the member nations, was consumer-oriented products while agricultural-related, intermediate, and bulk commodities follow in that order. The results of study are not different from the conclusions reached by Huchet-Bourdon, Le Mouël, and Vijil (2013), that globally, regional trade agreements generally enhance trade. In conclusion, it is evident that U.S. agricultural export has been significantly enhanced by the NAFTA and this was primarily driven by consumer- oriented products.

\section{ACKNOWLEDGEMENT}

This project was funded by the USDA-NIFA.

\section{REFERENCES}

Anderson, J.E., \& Van Wincoop, E. (2003). Gravity with gravitas: A solution to the border puzzle. The American Economic Review, 93(1), 170-192.

Beckman, J., Dyck, J., \& Heerman, K.E.R. (n.d.). The Global Landscape of Agricultural Trade, 19952014, EIB-181. U.S. Department of Agriculture, Economic Research Service, November 2017. Retrieved August 28, 2020, from https://www.ers.usda.gov/webdocs/publications/85626/eib181.pdf?v=269.7

Bishop, K.C., \& Simpson, C.E. (1972). Components of change analysis: Problems of alternative approaches to industrial structure. Regional Studies, 6(1), 59-68.

Carlberg, J., \& Rude, J. (2004). Canada-Mexico Agri-Food Trade under NAFTA. Revista Mexicana de Agronegocios, 15(1), 282-89.

Cooper, W.H. (2014). Free trade agreements: Impact on U.S. trade and implications for U.S. trade policy. Washington, DC: Congressional Research Service.

De Janvry, A., \& Sadoulet, E. (1997). NAFTA and agriculture: An early assessment (No. 1557-2016132628).

Deng, H., \& Nzuma, J.M. (2005). Assessing the Effects of NAFTA ON Canada/US Agricultural Trade (No. 724-2016-49227).

Eaton, J., \& Kortum, S. (2002). Technology, Geography, and Trade. Econometrica, 70(5), 1741-1779.

Elmslie, B.T., \& Maneschi, A. (2000). Comparative Advantage in International Trade: A Historical Perspective. Southern Economic Journal. https://doi.org/10.2307/1061441

Esteban-Marquillas, J.M. (1972). Shift-and-share analysis revisited. Regional and Urban Economics, 2(3), 249-61.

Fuchs, V.R. (1962, December). Statistical explanations of the relative shift of manufacturing among regions of the United States. In Papers of the Regional Science Association (Vol. 8, No. 1, pp. 105-126). Springer-Verlag.

Graham Shaw, D.J., \& Spence, N. (1998). A Productivity Growth Interpretation of the Labor Demand Shift-Share Model. Regional Studies, 32(6), 515-525. 
Herath, J., Gebremedhin, T.G., \& Maumbe, B.M. (2011). A Dynamic Shift-Share Analysis of Economic Growth in West Virginia. Journal of Rural and Community Development.

Huchet, M., Le Mouel, C., \& Vijil, M. (2013). The impact of regional trade agreements on agrifood trade flows: Agricultural vs. food products, developed vs. developing countries (No. hal-00979840).

Hufbauer, G.C., Cimino, C., \& Moran, T. (2014). NAFTA at 20: Misleading Charges and Positive Achievements. Policy Brief 14-13 (May). Washington: Peterson Institute for International Economics.

Krugman, P. (1980). Scale economies, product differentiation, and the pattern of trade. American Economic Review. https://doi.org/10.7551/mitpress/5933.003.0005

Markusen, A.R., Noponen, H., \& Driessen, K. (1991). International trade, productivity, and US regional job growth: A shift-share interpretation. International Regional Science Review, 14(1), 15-39.

North American Export Grain Association. (n.d.). North American Market Working Group of the U.S. Food and Agriculture Dialogue for Trade. Retrieved from http://naega.org/wpcontent/uploads/2017/06/Public-Comments_US-Food-Ag-Dialogue-NAmer_170612_FINAL.pdf

Oyewole, P. (2016). Regional Competition in the International Market for Services: $\bar{A}$ Shift-Share Analysis. Journal of Global Marketing. https://doi.org/10.1080/08911762.2015.1119918

Pouliot, S. (2017). The Importance of NAFTA for the Agricultural Sector. Agricultural Policy Review, 2017(3), 4. Retrieved August 24, 2020, from https://www.card.iastate.edu/ag_policy_review/article/?a $=73$

Reimer, J.J., \& Li, M. (2010). Trade costs and the gains from trade in crop agriculture. American Journal of Agricultural Economics, 92(4), 1024-1039.

Ricardo, D. (1817). On the Principles of Political Economy and Taxation. Library of Economics and Liberty. Retrieved July 4, 2020, from the https://web.archive.org/web/20180524101419/http://www.econlib.org/library/Ricardo/ricP2a.htm 1\#Ch.7,\%20On\%20Foreign\%20Trade

Ricci, L. (1997). A Ricardian Model of New Trade and Location Theory. Journal of Economic Integration, 12(1), 47-61. Retrieved July 08, 2020, from www.jstor.org/stable/23000280

Selting, A.L.S. (1992). A summary of the literature on shift-share analysis. Department of Agricultural and Applied Economics, University of Minnesota College of Agriculture St. Paul, Minnesota USA.

Soo, K.T. (2011). The gains from trade revisited. International Review of Economics \& Finance, 20(2), 193-201.

Trefler, D. (2004). The long and short of the Canada-U.S. free trade agreement. In American Economic Review. https://doi.org/10.1257/0002828042002633

United States International Trade Commission. (2019). Operation of the trade agreements program (Vol. 70 publication number 4986). Retrieved August 24, 2020, from https://www.usitc.gov/publications/332/pub4986.pdf

US International Trade Commission. (2016). Economic impact of trade agreements implemented under trade authorities' procedures, 2016 Report.

Villareal, M.A., \& Fergusson, I.F. (2017). The North American Free Trade Agreement (NAFTA) (CRS Report R42965). Washington, D.C.: Congressional Research Service. Retrieved August 24, 2020, from https://digitalcommons.ilr.cornell.edu/key_workplace/1937/

Viner, J. (1937). Studies in the Theory of International Trade. New York: Harper. A magisterial survey of pre- classical, classical, and neoclassical trade theories.

Williams, J. (1951). International Trade Theory and Policy--Some Current Issues. The American Economic Review, 41(2), 418-430. Retrieved July 21, 2020, from www.jstor.org/stable/1910817

Wilson, P., Chern, T.S., Ping, T.S., \& Robinson, E. (2005). Assessing Singapore's Export Competitiveness through Dynamic Shift- Share Analysis. Asean Economic Bulletin. https://oi.org/10.1355/ae22-2c

Zahniser, S., Angadjivand, S., Hertz, T., Kuberka, L., \& Santos, A. (2015). NAFTA at 20: North America's Free Trade Area and Its Impact on Agriculture. United States Department of Agriculture, Economic Research Service. 